\title{
HIRUNDOPORELLA DACHSTEINENSIS N. GEN., N. SP., A NEW PROBLEMATIC DASYCLADALE (GREEN ALGA) FROM THE UPPER TRIASSIC OF THE NORTHERN CALCAREOUS ALPS, AUSTRIA.
}

\author{
FELIX SCHLAGINTWEIT ${ }^{1}$, HARALD LOBITZER $^{2} \&$ OSKAR EBLI $^{3}$
}

\begin{abstract}
A new problematic dasycladale is described as Hirundoporella dachsteinensis nov. gen., n. sp. from the Upper Triassic bedded Dachstein Limestone of Mount Dachstein, Austria. It is characterized by individualized phloiophorous laterals, open at the ends and secondary laterals of low number arising in the middle part of the primaries. Nothing is known about the obviously thin and poorly calcified main-axis and the overall arrangement of the primaries. The microfacies is represented by a wackestone composed to about $70 \%$ of dismembered laterals of Hirundoporella dachsteinensis n. sp.
\end{abstract}

Key Words: Calcareous Algae, Dasycladales, Upper Triassic, Norian-Rhaetian, Dachstein Limestone, Northern Calcareous Alps, Austria

\section{INTRODUCTION}

The Austroalpine Dachstein nappe with the Dachstein mountains is part of the Triassic shallow marine carbonate shelf that at its southern rim bordered the Tethys ocean with the adjacent deeper water Hallstatt realm (e.g. Haas et al., 1995, Mandl 2000). The Upper Triassic Dachstein-type platforms are widespread in the Mediterranean realm and even Japan (Kristan-Tollmann 1991). The Dachstein facies comprises reefs at the southern border, northward passing into back-reef and lagoonal deposits of the so-called "bedded Dachstein limestone" (e.g. Zankl 1971). The latter exhibits a typical cyclicity, the so-called "Lofer cyclothems" (layer A, B, C) studied by Fischer (1964). With respect to the reefal and near-reef facies, a more detailed differentiation has been established with typical assemblages of benthic foraminifera and dasycladales (Senowbari-Daryan \& Schäfer, 1978, 1979; Wurm, 1982). Summaries of the microflora of the alpine Upper Triassic reefs and platform carbonates have been provided by Flügel (1975), Senowbari-Daryan \& Schäfer (1979) and Senowbari-Daryan \& Flügel (1993). The compilation of the latter authors lists

- 8 species in the Anisian

- 7 species in the Ladinian

- 5 species in the Carnian

- 10 species in the Norian and

- 11 species in the Rhaetian.

\footnotetext{
${ }^{1}$ Lerchenauerstr. 167, 80935 München, Germany

${ }^{2}$ Rasumofskygasse 23, 1031 Wien, Austria

${ }^{3}$ C/o Institute for Palaeontology, Richard-Wagner-Str. 10, 80333 München, Germany
} 
The Norian-Rhaetian inventory of Senowbari-Daryan \& Flügel (1993) is supplemented by new findings of calcareous algae in the Dachstein limestone namely Chinianella macropora (Di Stefano \& Senowbari-Daryan) (unpublished data), Salpingoporella austriaca Schlagintweit, Mandl \& Ebli (2001), Coptocampylodon? rhaeticus Schlagintweit, Gawlick \& Missoni (2002). The higher number of species in the Upper Triassic of the Northern Calcareous contrasts the overall trend where the Middle Triassic yields much more species than the Upper Triassic (e.g. Barattolo 1991, Bucur, 1999, Flügel, 1991).

Another new problematic dasycladale is described in the following as Hirundoporella dachsteinensis nov. gen., nov. sp. also from the Dachstein Limestone of the type region, the Dachstein mountains in the Austrian Salzkammergut.

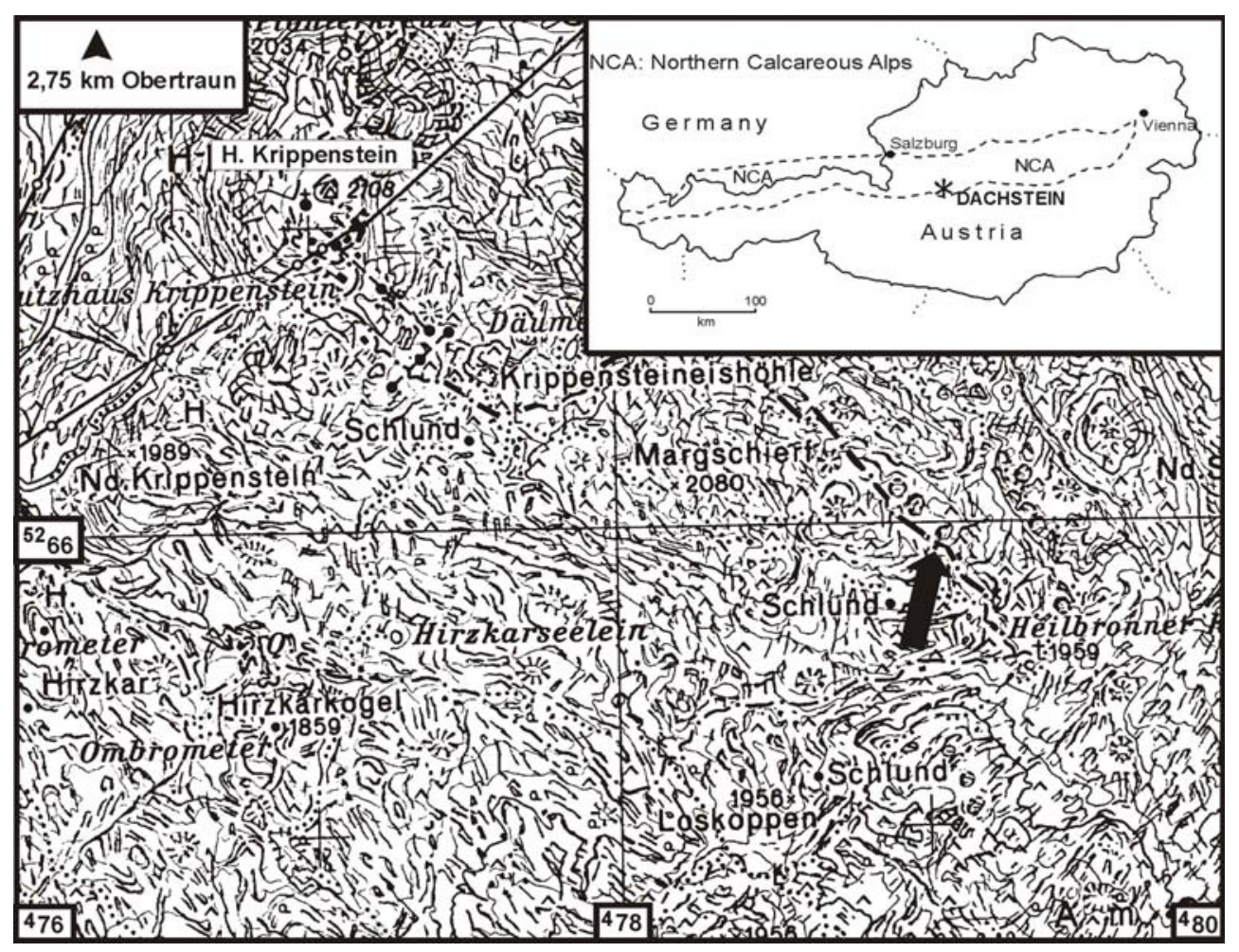

Fig.1 - Location map of the type locality of Hirundoporella dachsteinensis nov. gen., $n . s p$.

\section{SYSTEMATIC DESCRIPTION}

Order Dasycladales PASCHER 1931

Hirundoporella, n. gen.

Genotype: Hirundoporella dachsteinensis, n. gen., n. sp. The genus is so far monospecific. 
Origin of the name: Hirundo in Latin, for swallow since the longitudinal sections reminds the tail of a swallow.

Diagnosis:

Weakly calcified central tube bearing individualised, well-calcified primary branches of phloiophorous shape open at the ends. In the middle portion of the primaries secondary branches of low number occur.

Affinities and differences:

As we favour a dasycladale nature of Hirundoporella nov. gen. the generic and species description is presented in terms of dasycladale terminology. The presence of individualised laterals and the occurrence of secondaries are known from the genus Rajkaella DRAGASTAN \& BUCUR, 1988. In the latter genus, however the short secondaries occur at the rounded swollen part of the primaries appearing like a bush (rosette). In addition, the primaries are closed at their ends (for discussion see Granier, 1989, Granier \& Berthou, 1994, Dragastan \& Bucur, 1993). As is also the case in Rajkaella, nothing is known about the arrangement of the laterals with the main axis. With respect to the thin-section appearance of the longitudinal sections there are striking similarities to the genus Probolocuspis BRÖNNIMANN, ZANINETTI, MOSHTAGHIAN \& HUBER (type-species P. espahkensis BRÖNNIMANN et al., 1974, Carnian of Iran). Recently, this former microfossil incertae sedis has been attributed to the dasycladales by Senowbari-Daryan \& Majidifard (2003). This large sized dasycladale has laterals that when disintegrated show similar sections as Hirundoporella n. gen. ("tooth-like elements" of Brönnimann et al. 1974). The general shape, however, is the only common feature with Probolocuspis since the latter only has primary branches. Moreover, the laterals are trichophorous in Probolocuspis with the broader part connected to the main axis. In Hirundoporella nov. gen. instead we favour another interpretation of the branch arrangement assuming that the smaller, tapering part representing the proximal portion.

The occurrence of secondary branches approximately in the middle part of the primaries is unusual in dasycladales. An example for the latter is the Cenomanian Acroporella? hamata Kuss. Normally the secondaries split off from the primaries at their distal endings (e.g. Fig. 1 in Deloffre \& Genot, 1979). For this reason we approach Hirundoporella n. gen. a somehow problematic dasycladale, nonetheless the general morphological appearance is in accordance with this order of green algae.

The primaries could generally be spaced out along the axis without contact as in the genus Clypeina or forming multiple whorls as known from Milanovicella GRANIER \& BERTHOU 1994. Hence, also nothing is known whether the laterals were originally alternating or not in position between two successive whorls or may even be distributed in an irregular manner.

The general shape of the laterals of Hirundoporella nov. gen. furthermore resembles those from Milanovicella GRANIER \& BERTHOU or Falsolikanella GRANIER, both, however, lack secondary branches (see fig. 3 in Granier \& Berthou, 1994).

Another genus with individualised laterals is Humiella SoKAC that, in contrast to Hirundoporella nov. gen. has no secondary branches and primaries are closed at tips. Furthermore, the laterals of Humiella are perforated by tiny tubes (Sokac 1987, 2001).

The genus Hirundoporella is so far monospecific. 
Hirundoporella dachsteinensis, n. gen. n. sp.

(PI. I, Fig. 1-7, PI. II, Figs 1-8, PI. III, Figs 1-9)

Diagnosis:

Representative of Hirundoporella with primaries bearing 4 secondary laterals regularly arranged (angle of $90^{\circ}$ between adjacent secondaries).

Holotype:

The left specimen figured in Plate 3, fig. 3 representing a longitudinal-tangential section. The thin-section containing the holotype with the no. BSP 2003 X-8 is stored at the "Bayerische Staatssammlung für Paläontologie und Historische Geologie", University of Munich and three other thin-sections (no. BSP 2003 X-7, X-9, X-10) are stored at the Bayerische Staatsssammlung für historische Geologie und Paläontologie, University of Munich.

\section{Paratypes:}

All specimens figured besides the holotype.

Type locality:

The type locality is Mount Dachstein, about 2,3 km southeast of the $H$. Krippenstein (2108 $\mathrm{m}$ a. s.-I.). It can be found on the topographic map of Austria, ÖK 1 : 25.000, no. 96 Bad Ischl and the Geological Map of Austria, ÖK $1: 50.000$, no. 96 Bad Ischl. Access to the type-locality is possible by using the cable car from Obertraun at Lake Hallstatt to the summit of the Krippenstein (2108 m a. s.-I.), then following the route to the Heilbronner Kreuz (1959 m a. s.-I.) (see Text-Fig. 1).

Type horizon:

The sediment bearing the new species can be classified as a wackestones composed almost exclusively of dismembered laterals of Hirundoporella dachsteinensis $\mathrm{n}$. sp. Except some recrystallized involutinid foraminifera no other biota have been detected. The microfacies in the surrounding of the Hirundoporella-bearing horizon comprises microfossil-free laminated bindstones with large solution cavities, and sometimes distinct layers of onkoids. But also somewhat "deeper" water sediments with a higher content of ostracodes, or packstones rich in Involutinid foraminifera occur. Samples that were taken in the lateral continuation of sample KL 7/8 are represented by wacke- to packstones also with fragments of Hirundoporella dachsteinensis $\mathrm{n}$. $\mathrm{sp}$. Summarizing the facies with the new taxon typically belongs to the lagoonal bedded type Dachstein Limestone. No direct stratigraphic determination can be given, but the Dachstein Limestone is generally of Norian-Rhaetian age (e.g. SenowbariDaryan \& Flügel, 1993, Mandl 2000).

Diagnosis:

see species description

Material:

Seven thin-sections from one sample each containing more than hundred variously oriented sections of disintegrated laterals. The original sample number is $\mathrm{KI} 7-8$; those kept at the official depository have BSP numbers. 


\section{Description:}

Due to the disintegrated laterals in our material, the description focuses on their morphology. The branches are preserved as light sparry calcite with a maximum length of up to $0,98 \mathrm{~mm}$ having the shape of a trumped with only a slightly increasing diameter (inner and outer) in the first $2 / 3$ of their lenght. The last $1 / 3$ part shows an abrupt widening. The greatest wall thickness is attained in this area whereas towards the distal ending it is tapering. At the proximal and distal parts, there's only a reduced calcareous sheet around the branches. In the proximal part of the laterals the inner diameter is in the range of $0,016-0,024 \mathrm{~mm}$ at the distal ending it extends to a maximum of $0,42 \mathrm{~mm}$. In the middle portion of the primaries where these abruptly widen, 4 secondary branches arise perpendicular to the longitudinal axis of the primaries. These are regularly arranged with a constant angle of $90^{\circ}$ between two secondaries (Text-Fig.2). Regarding the general shape, it is comparable to the primaries also beginning rather narrow and abruptly widening in the last part. In longitudinal section it can be seen, however, that the secondaries are vertically compressed leading to oval cross-sections. Cross-sections of the primaries at their distal parts are round in shape whereas in the height slightly above or below the secondaries we have flower shape sections.

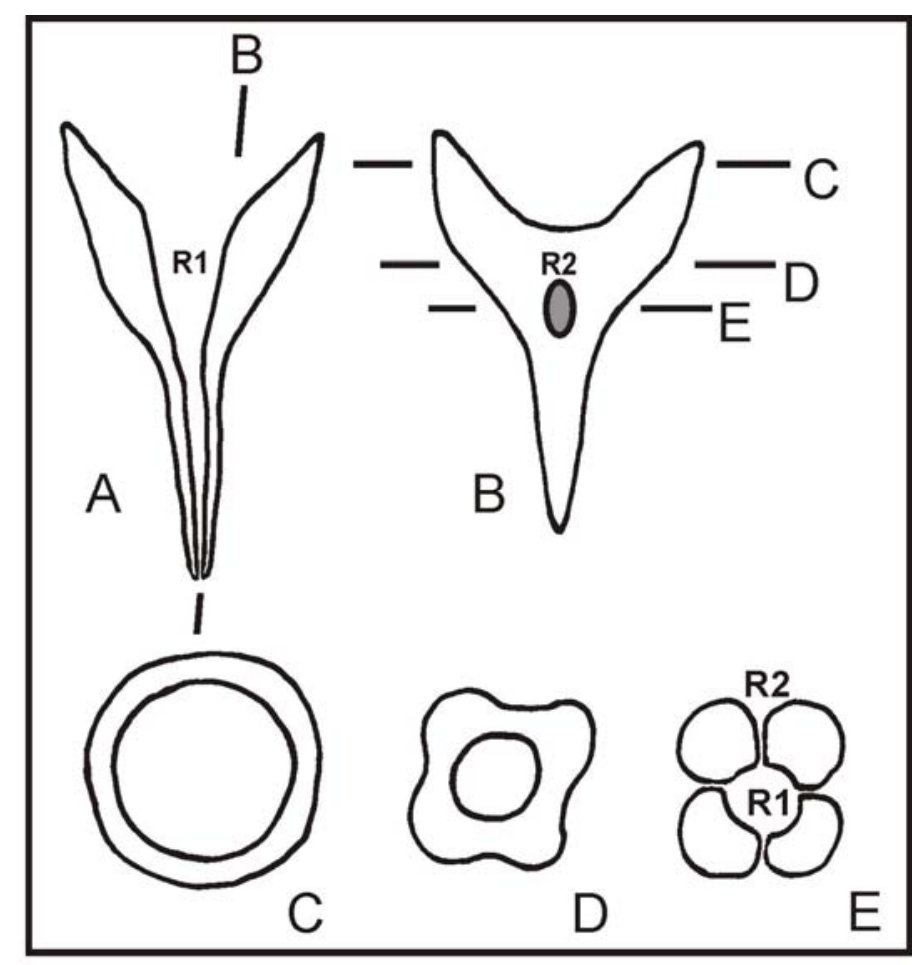

Fig. 2 - Laterals sections of Hirundoporella dachsteinensis $n$. sp. (without scale). Note the hypothetical proximal-distal orientation. Section A: see pl. I, fig. 3-5; section B: see pl. 3, fig. 3, 6-7; section C: see pl. 1, fig. 6; section D: see pl. 2, fig. 6; section E: see pl. 3, fig. 8-9. 
One section with some laterals adjacent to each others could represent a relict of the original branch configuration. In any case, the central cavity must have been comparable wide, probably $>2-3 \mathrm{~mm}$ in diameter and the number of laterals $(\mathrm{w})$ although with uncertainties $>13-15$. Another questionable section could be interpreted as close set laterals, perhaps arranged in the way of a double verticil, but, however, this is not clearly evidenced. Summarizing, for the moment being the arrangement of the primaries with respect to the main axis and also some important biometric parameters must remain open.

\section{CONCLUSIONS}

The finding of a new dasycladale in the Upper Triassic Dachstein limestone give further evidence of the greatest diversification of the Dasycladales during the Norian-Rhaetian interval in the Northern Calcareous Alps with respect to the Middle Triassic. Although the Alpine Dachstein has been studied by various workers, never has the new alga been mentioned or illustrated. Hence, either a restricted occurrence (geographically or from facies point of view) or reduced stratigraphic range can be assumed.

\section{Acknowledgements}

Some remarks of Marc Conrad (Geneva) and Ioan Bucur (Cluj-Napoca) are kindly acknowledged.

\section{REFERENCES}

Barattolo, F. 1991, Mesozoic and Cenozoic marine benthic calcareous algae with particular regard to Mesozoic dasycladaleans. In: Riding, R. (ed.), Calcareous algae and stromatolites, p. 504-540, (Springer).

Brönnimann, P., Zaninetti, L., Moshtaghian, A \& Huber, H. 1974, Foraminifera and microfacies of the Triassic Espahk Formation, Tabas area, east central Iran. Rivista Italiana Paleontologia, $80 / 1$, p. $1-48$.

Bucur, I.I. 1999, Stratigraphic significance of some skeletal algae (Dasycladales, Caulerpales) of the Phanerozoic. In: Farinacci, A. \& Lord, A.R. (eds.): Depositional episodes and bioevents, Palaeopelagos Spec. Pub., 2, p. 53-104.

Deloffre, R. \& Genot, P. 1979, Détermination générique des Dasycladales du Cénozoique a l'actuel. Bulletin Centres Recherches Exploration-Production Elf-Aquitaine, 3/2, p. 545-556.

Dragastan, O. \& Bucur, I.I. 1993, The Dasyclad genus Radoiciciella and ist representatives from Romania. Revista Espanola de Micropaleontologia, 25/2, p. 5-23.

Fischer, A.G. 1964, The Lofer cyclothems of the Alpine Triassic. Bulletin Geological Survey Kansas, 169, p. 107-149.

Flügel, E. 1975, Kalkalgen aus Riffkomplexen der alpin-mediterranen Obertrias. Verhandlungen Geologischen Bundesanstalt Wien, Jg. 1974, 2-3, p. 297-346. 
Flügel, E. 1991, Triassic and Jurassic marine calcareous algae: a critical review. In: Riding, R. (ed.): Calcareous algae and stromatolites, p. 481-503 (Springer).

Granier, B., 1989, The case of the genus Radoiciciella, Dasycladalean algae from the Tethyan Upper Jurassic and Lower Cretaceous. Comun. Serv. Geol. Portugal, 75, p. 29-37.

Granier, B. \& Berthou, P.-Y. 1994, Description de Milanovicella momciliana n. gen., n. sp., aldue dasycladale du Portlandien de l'Algarve Central (Portugal), et validation de quelques taxons affins. Revue de Micropaléontologie, 37/2, p. 113-121.

Haas, J., Kovács, S., Krystin, L. \& Lein, R. 1995, Siginificance of Late Permian-Triassic facies zones in the terrane reconstructions in the Alpine-North Pannonian domain. Tectonophysics, 242, p. 19-40.

Kristan-Tollmann, E. 1991, Triassic Tethyan microfauna in Dachstein Limestone blocks in Japan. Saito Ho-on Kai Special Publication, 3 (Proceedings of Shallow Tethys 3, Sendai, 1990), p. 35-49.

Mandl, G.W. 2000, The Alpine sector of the Tethyan shelf - Examples of Triassic to Jurassic sedimentation and deformation from the Northern Calcareous Alps. Mitteilungen der österreichischen geologischen Gesellschaft, 92, p. 61-77.

Schlagintweit, F., Mandl, G.W. \& Ebli, O. 2001, Salpingoporella austriaca n. sp., a new dasycladale (calcareous alga) from the Lower Norian Dachstein Limestone of Mount Dachstein (Northern Calcareous Alps, Austria). Revue de Paléobiologie, 20/2, 359-365.

Schlagintweit, F., Missoni, S. \& Gawlick, H.-J. 2002, Coptocampylodon? rhaeticus n. sp., a new new problematic microfossil from the Rhaetian Dachstein Limestone of the Northern Calcareous Alps (Germany, Austria). Geologica Croatica, 55/2, p. 1-14.

Senowbari-Daryan, B. \& Flügel, E. 1993, Triassic reefs and platform carbonates in the Northern Calcareous Alps. - Alpine Algae, Field Trip Guide Book, A1, p. 1-35.

Senowbari-Daryan, B. \& Schäfer, P. 1978, Die Häufigkeitsverteilung der Foraminiferen in drei oberrhätischen Riff-Komplexen der Nördlichen Kalkalpen (Salzburg, Österreich). Verhandlungen der geologischen Bundesanstalt Wien, Jg 1978, 2, p. 73-96.

Senowbari-Daryan, B. \& Schäfer, P. 1979, Distributional patterns of calcareous algae within Upper Triassic patch reef structures of the Northern Calcareous Alps (Salzburg). Bulletin Centres Recherches Exploration-Production Elf-Aquitaine, 3/2, p. 811-820.

Senowbari-Daryan, B. \& Majidfard, M.R. 2003, A Triassic "Problematic Microfossil" revealed: Probolocuspis espahkensis Brönnimann, Zaninetti, Moshtaghian and Huber 1974 is attributed to the Dasycladacean algae. Facies, 48, p. 107-114.

Sokac, B. 1987, On some controversial Dasyclad genera and species and their stratigraphic position in the Lower Cretaceous deposits of the Dinarides. Geol. Vjesnik, 40, p. 9-38.

Sokac, B. 2001, Lower and Middle Liassic calcareous algae (Dasycladales) from Mt. Velebit (Croatia) and Mt. Trnovski Gozd (Slovenia) with particular reference to the genus Palaeodasycladus (Pia, 1920) 1927 and its species. Geologica Croatica, 54/2, p. 133-257.

Wurm, D. 1982, Mikrofazies, Paläontologie und Palökologie der Dachsteineiffkalke (Nor) des Gosaukammes, Österreich. Facies, 6, p. 203-296.

Zankl, H. 1971, Upper Triassic carbonate facies in the Northern Limestone Alps. In: Müller, G. (ed.), Sedimentology of parts of Central Europe, Guidebook. $8^{\text {th }}$ int. sed. Congr. (Heidelberg), p. 147185. 


\section{PLATES}

\section{Plate I}

Hirundoporella dachsteinensis nov. gen., nov. sp. Upper Triassic Dachstein limestone of Dachstein Mountains

Fig. 1 - Wackestone facies with abundant dismembered laterals and some recrystallized involutinids (e.g. upper left side). Thin-section BSP $2003 X-7$, scale bar $=2 \mathrm{~mm}$.

Fig. 2, 7 - Longitudinal oblique sections. 2-thin-section BSP 2003 X-7, scale bar $=0,5$ $\mathrm{mm}$; 7-thin-section BSP 2003 X-7, scale bar $=0,5 \mathrm{~mm}$.

Fig. 3 - Longitudinal oblique section (left) and longitudinal section (right). Thin-section BSP 2003 X-7, scale bar $=0,5 \mathrm{~mm}$

Fig. 4-5 - Longitudinal sections. 4-thin-section BSP 2003 X-7, scale bar = 0,5 mm; 5-thinsection BSP $2003 X-7$, scale bar $=0,5 \mathrm{~mm}$.

Fig. 6 - Three transverse sections, partly oblique. Thin-section BSP 2003 X-7, scale bar = $0,5 \mathrm{~mm}$.

\section{Plate II}

Hirundoporella dachsteinensis nov. gen., nov. sp. Upper Triassic Dachstein limestone of Dachstein Mountains

Fig. 1 - Possible fragment showing original branch arrangement. Thin-section BSP 2003 $X-7$, scale bar $=0,5 \mathrm{~mm}$.

Fig. 2 -Transverse section through distal part of primary branch. Thin-section BSP 2003 $\mathrm{X}-8$, scale bar $=0,5 \mathrm{~mm}$.

Fig. 3, 5 - Longitudinal-tangential sections. 3-thin-section BSP 2003 X-8, scale bar $=0,5$ $\mathrm{mm}$; 5-thin-section BSP $2003 \mathrm{X}-7$, scale bar $=0,5 \mathrm{~mm}$.

Fig. 4 - Two transverse sections, slightly oblique. Thin-section BSP 2003 X-8, scale bar = $0,5 \mathrm{~mm}$.

Fig. 6 - Transverse section slightly oblique (middle) and recrystallizied involutinid foraminifera (right). Thin-section BSP $2003 X-7$, scale bar $=0,5 \mathrm{~mm}$.

Fig. 7-8 - Oblique sections through the distal branch portion. 7-thin-section BSP 2003 X-9, scale bar $=0,3 \mathrm{~mm}$; 8-thin-section BSP $2003 \mathrm{X}-9$, scale bar $=0,3 \mathrm{~mm}$.

\section{Plate III}

Hirundoporella dachsteinensis nov. gen., nov. sp. Upper Triassic Dachstein limestone of Dachstein Mountains

Fig. 1-5 - Oblique sections showing secondary branches.1-thin-section BSP 2003 X-7, scale bar = 0,5 mm; 2-thin-section BSP $2003 \mathrm{X}-8$, scale bar $=0,5 \mathrm{~mm}$; 3-thinsection BSP $2003 X-8$, scale bar $=0,5 \mathrm{~mm}$, holotype left specimen; 4-thinsection BSP 2003 X-8, scale bar = 0,5 mm; 5-thin-section BSP 2003 X-9, scale bar $=0,5 \mathrm{~mm}$.

Fig. 6-7 - Tangential sections showing secondary branches. 6-thin-section BSP $2003 X-$ 10 , scale bar $=0,5 \mathrm{~mm} ; 7$-thin-section BSP $2003 \mathrm{X}-7$, scale bar $=0,5 \mathrm{~mm}$.

Fig. 8-9 - Transverse sections, slightly oblique showing four secondaries. 8-thin-section BSP 2003 X-9, scale bar = 0,3 mm; 9-thin-section BSP 2003 X-7, scale bar = $0,3 \mathrm{~mm}$. 
PLATE I
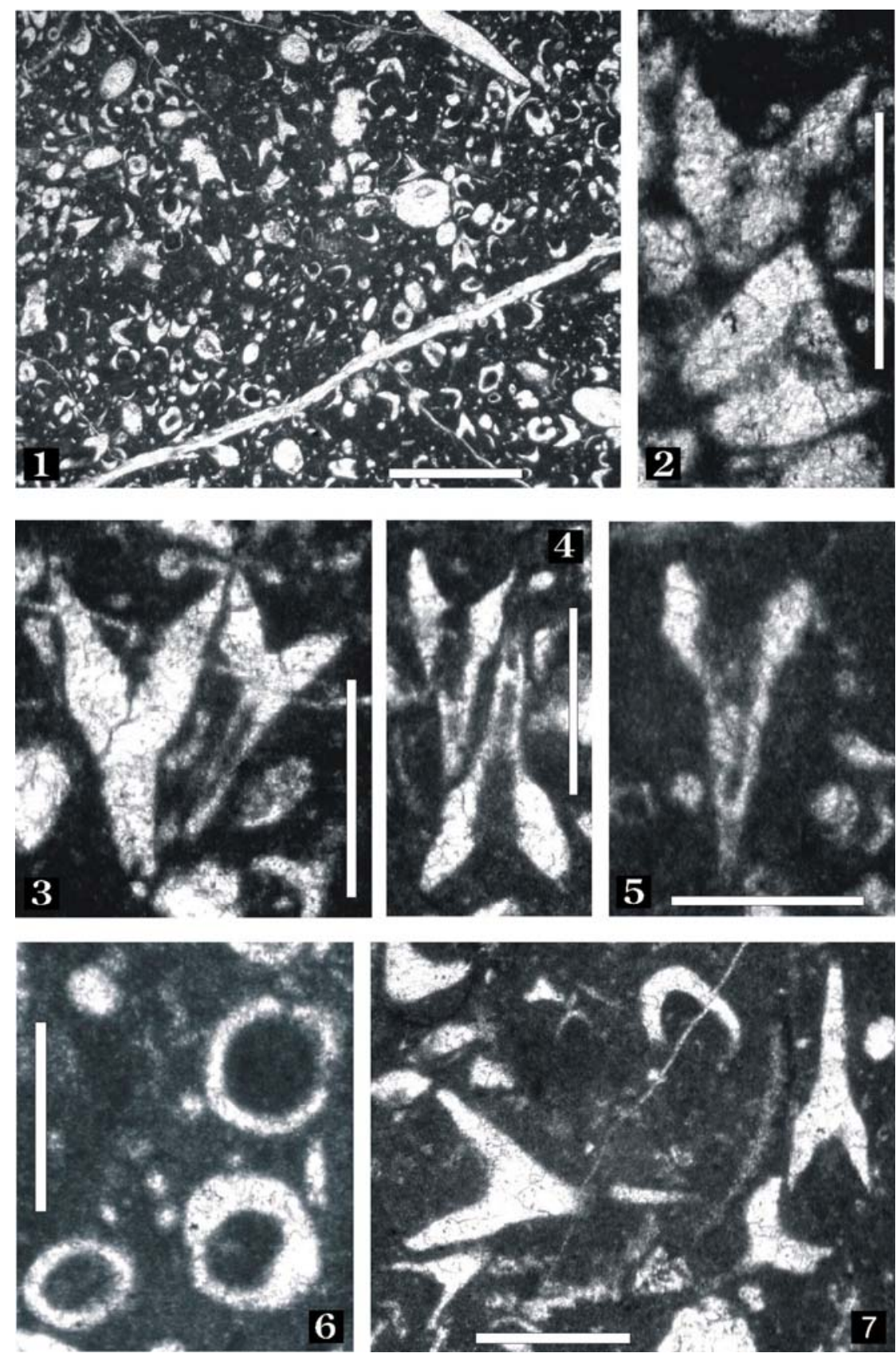

IE II 
FELIX SCHLAGINTWEIT, HARALD LOBITZER \& OSKAR EBLI
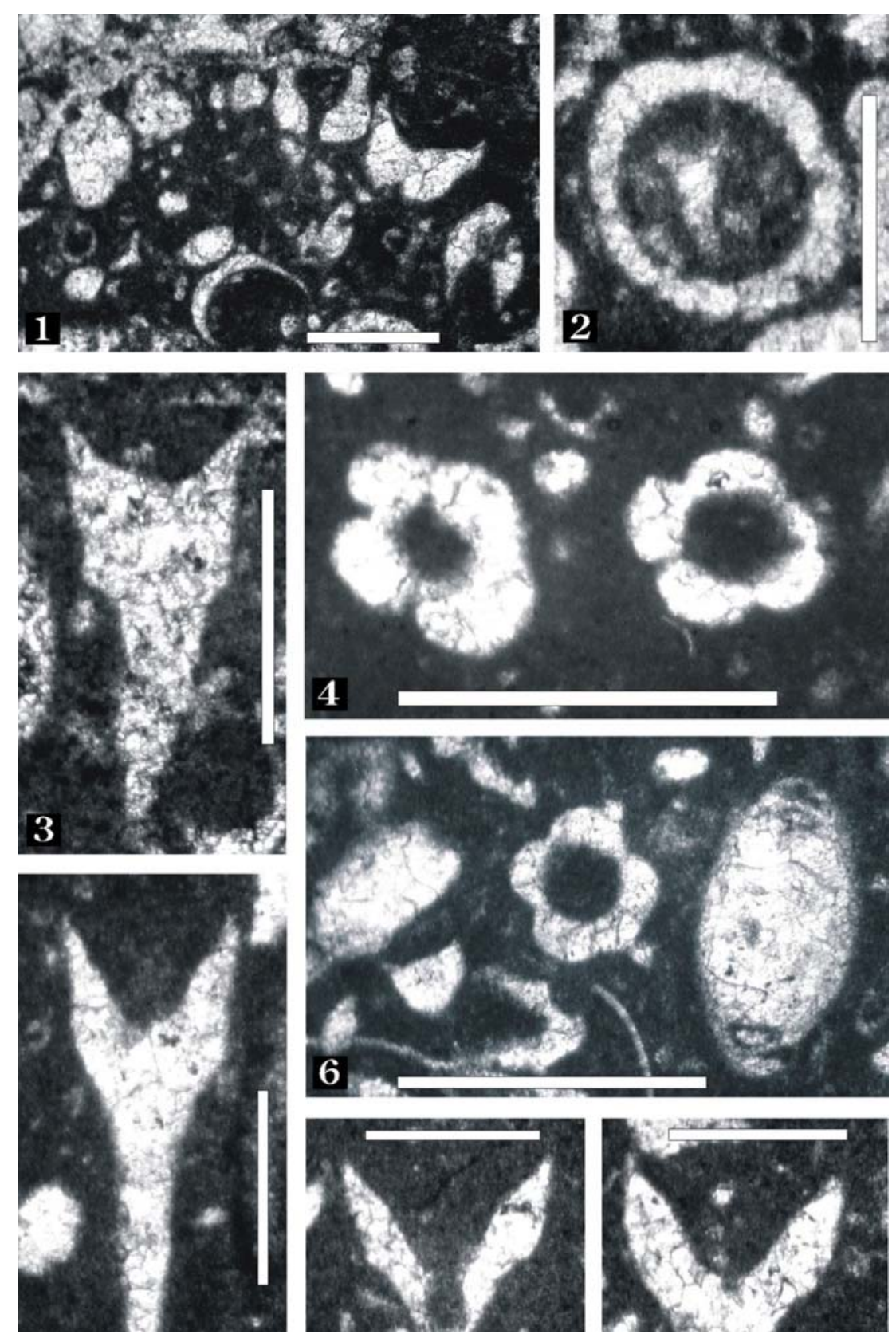
PLATE III
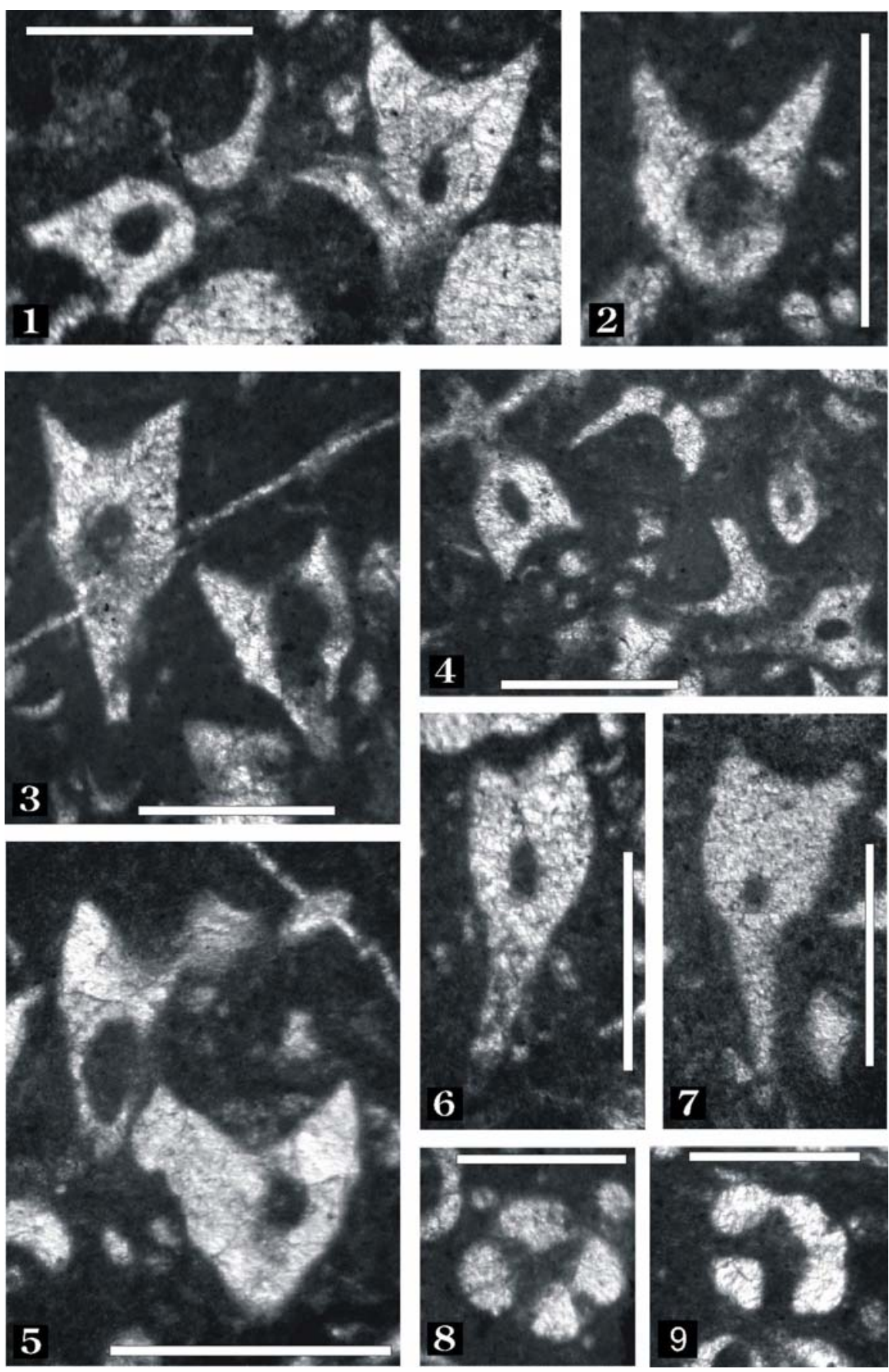